NEIGHBORLY CONDUCT versUS PROPERTY IN MINERALS.

In Higgins Oil \& Fuel Company v. Guaranty Oil Company, Ltd. (I9I9, La.) 82 So. 206, the defendant's duty to be neighborly was upheld and his privileges in using his land to dig for oil were correspondingly narrowed. The defendant had sunk an oil well on his land which caused air to get into the plaintiff's pump in a well on the latter's land, resulting in a great decrease in the productivity of the plaintiff's well. Although the defendant's well was a non-producer and could be closed without trouble or expense by simply putting back a plug, the defendant refused to close it. The court discusses both civil and common-law authorities and decides that the plaintiff is entitled to relief.

The decision in its delimitation of the point where the defendant's privileges resulting from ownership cease, and the plaintiff's rights begin, is in accord with the position taken by Professor Summers in his article in this number of the Journal. 1 While agreeing entirely with Professor Summers' conclusions, the writer suggests that an analysis distinguishing between plaintiff's rights and defendant's privileges would have made his points even clearer than they now appear. For it would seem that courts, at least partly because of the use of complex conceptions, have taken a long road in order at length to reach a near goal.

As Professor Summers shows, the development of the law both of percolating streams and of oils and gases has been in this wise. Courts have seen before them the interest of the owner of the land where such minerals are found, and from this view have stated the "absolute ownership" doctrine, namely, that the landowner is the absolute owner of the minerals either solid or fluid or gaseous found on or in his land. This rule was found to do injustice to the neighboring landowner, and the opposite extreme was then suggested, that is, that one does not "own" such minerals until they are definitely appropriated. It does not seem to have been perceived that ownership was merely a term referring to an aggregate of legal relations in the "owner" and hence denoted the number rather than the kind of such relations, nor that there was no fixed number of such relations beyond which the ownership would be "absolute" instead of "qualified." A realization of this meaning of the term would have developed that "absolute ownership" was not inconsistent with certain duties to one's neighbor as regards the subject matter of ownership. But the courts went to the other extreme and are only now coming back to the middle view which recognizes that in the legal relations which go to make up ownership of oils and gases, there are in both landowner and neighbor duties in addition to privileges (in the cases often termed rights), as well as

2 (1919) 29 Yale Law Journal, I74.

${ }^{2}$ Cook (Igrg) 28 Yale Law Journal, 729. 
numerous other legal relations. ${ }^{3}$ Thus the landowner has a privilege and a power of appropriation of minerals in his land, while his neighbor has a like privilege and power, and each are subject to the liability to have such appropriation made by the other." But each owes the other a duty not to waste or pollute such minerals, and the courts will enforce this duty. ${ }^{5}$

It is not suggested that this analysis settles the ultimate question, which is where the line between the privileges of one and the rights of the other should be drawn. That question can only be settled by weighing the arguments based upon public policy and convenience. It is urged, however, that it does bring the court shortly to this ultimate question without filming it over by such indefinite terms as absolute ownership. And therefore the courts should more shortly reach the necessary result, that is, the decision as to what public policy does require in this particular instance.

The principal case presented less question on this point than many others, for there the defendant did not even benefit himself by his act. In the case of percolating water there is much authority to the effect that one may be restrained from committing acts which without benefit to himself deprive his neighbor of such water. ${ }^{\circ}$ And this tendency to give a plaintiff a remedy where the only effect of the defendant's acts is to damage the plaintiff without gain to the defendant, may be found in the law of torts generally. ${ }^{7}$ Our ideas of property may not have advanced to the point where this tendency may be developed in the case of ownership of the land itself, but it certainly may be given effect in a case where, as with minerals, the interests of adjoining landowners seem of equal merit and hence the conflict to extend the rights of one and the privileges of the other, is the sharper.

C. E. C.

\section{"RENVOI” IN THE CONFLICT OF LAWS}

A decision of the French Court of Cassation, known as the Forgo Case. ${ }^{1}$ raised a problem of the most fundamental importance in the

\footnotetext{
8 "There is a middle ground between the existence of an absolute and indefeasible right and the absence of any right that the law will recognize and protect. There is room for the existence of qualified and correlative rights in both landowners." Meeker v. City of East Orange (1909, Ct. Err.) 77 N. J. L. 623, 74 At1. 379.

So stated in the principal case. See also cases cited by Professor Summers, p. 176 , note 9 , supra.

${ }^{5}$ Cases cited p. 184 , notes 30 and 31 , supra.

- Gagnon v. French Lick Springs Hotel Co. (1904) I63 Ind. 687, 72 N. E. 849, 68 L. R. A. I75, note; Barclay v. Abraham (1903) I2I Iowa, 6I9, 96 N. W. 1080; Stillwater Water Co. v. Farmer (1903) 89 Minn. 58, 93 N. W. 907 ; contra, Phelps v. Nozelen (1878) 72 N. Y. 39; Bradford v. Pickles, L. R. [1895] A. C. 587; Chatfield v. Wilson (1855) 28 Vt. 49. Cases are collected at p. 176 , note 6 , supra.

(I9I8) 28 Yale Law Journal, 507; (Ig07) 20 Harv. L. Rev. 262-3.

${ }^{1}$ Cass. June 24, 1878, Dalloz, I879, I, 56.
} 